Kinestetik : Jurnal Ilmiah Pendidikan Jasmani 5 (1) (2021)

Kinestetik : Jurnal Ilmiah Pendidikan Jasmani

https://ejournal.unib.ac.id/index.php/kinestetik/index

DOI : 10.33369/jk.v5i1.14616

\title{
IMPROVING LEARNING OUTCOMES OF BIG BALL GAMES USING COOPERTIVE METHODS IN PRIMARY SCHOOLS
}

\author{
Ramadhan Arifin $^{1 *}$, Mita Erliana ${ }^{2}$, Ahmad Faisal ${ }^{3}$ \\ ${ }^{123}$ Faculty of Teacher Training Education, Universitas Lambung Mangkurat, Indonesia
}

\section{Article Info}

Article History :

Received : February 2021

Revised : February 2021

Accepted : March 2021

Available online : March 2021

Keywords:

Big Ball, Cooperative, Physical Education

\begin{abstract}
The purpose of this study is the application of the cooperative learning model in order to improve the learning outcomes of big ball games in class III students of SDN 1 Landasan Ulin Tengah Banjarbaru. The method used in this study is a classroom action research method, namely the researcher as an observer. Observations at the time the teaching and learning process takes place. The subjects of this study were 27 students of class III (three) at SD Negeri 1 Landasan Uling Tengah Banjarbaru for the 2019/2020 academic year, consisting of 16 boys and 11 girls. The process of increasing the ability of learning outcomes in the manipulative motion material of big ball games by emphasizing the cooperative learning model, getting good results based on the predetermined KKM, which is 75. Defined results through cooperative learning model can improve student learning outcomes in motion manipulative big ball game with the following average: Observation of the first meeting was an average value of 70.1 The number of students who reached KKM 75 was 9 students with a percentage of $33.33 \%$ and the number of students who did not reach the KKM was 18 students with a percentage of $66.67 \%$. and at the second meeting the average value was 85.5 , the number of students who reached KKM 75 was 27 students with a percentage of $100 \%$ and the number of students who did not reach the KKM was 0 students with a percentage of $0 \%$ so this research was stopped at the second meeting (II).
\end{abstract}

Corresponding address : Jl. Brigjen H. Hasan Basri, Pangeran

Kec. Banjarmasin Utara, Kota Banjarmasin, Kalimantan Selatan

Email : ramadhan.arifin@ulm.ac.id
ISSN 2685-6514 (Online)

ISSN 2477-331X (Print) 


\section{INTRODUCTION}

Physical education is an integral part of education as a whole, aims to develop aspects of physical fitness, movement skills, critical thinking skills, social skills, reasoning, emotional stability, moral action for healthy living patterns and introduction to clean environments through selected physical activities that are planned systematically in in order to achieve educational goals (Rahayu, 2013)

To help the running of Sports and Health Physical Education or abbreviated (PJOK) in schools and educational equality, the foundation is the curriculum. The curriculum is a guide in implementing learning in schools. (Kusmana, 2017) states that "the curriculum is a program that is planned and implemented in schools". In carrying out the learning process in schools, teachers must understand the curriculum. Each implementing teacher learning will definitely be involved with the curriculum. The curriculum is a printed matter, the curriculum is an "inanimate" object, only the teacher gives "life" to the curriculum.

Therefore the teacher is always the main figure in realizing the curriculum so that student behavior changes according to what is expected (Vusparatih, 2014). Therefore, further development of the learning curriculum, shows that the role of the teacher is very important because the teacher is directly involved in the learning process in the classroom. Based on observations in class III, especially on big ball game material, it tends to reflect a rigid coaching approach, leading to sporting ramifications. What I want to achieve in physical education is solely the aspect of physical skills, while the cultivation and appreciation of the value of Physical Education is completely neglected. The presentation of the material should pay attention to differences in the diversity of students' characters both horizontally (differences in class) and vertically (differences in class levels), so that students carry out activities happily because they are according to their abilities. As a result, students tend to be indifferent, lack motivation in learning, feel bored and lack self-confidence.

The lack of physical education facilities and infrastructure owned by schools is also a factor in the lack of effectiveness in learning big ball games. For this reason, it is necessary for a teacher to master learning strategies, so that the material is conveyed effectively and efficiently so that learning objectives are achieved (Pramono, 2012).

The cooperative learning model will be more suitable to be applied to the manipulative motion material of this big ball game because it is in accordance with the characteristics of the child, namely happy in groups and playing (interacting). (Johnson, D. W., \& Johnson, 2011). From this group learning model is an effort to help solve problems in the presentation of material and infrastructure in schools. According to the opinion (Subiantoro, 2013) group learning methods can improve physical education learning. Furthermore, according to (Suherman, 
2016) that there is a significant increase to improve the Physical Education learning process with the group method.

As well as innovative learning with the creation of fun learning and can motivate students to have more opportunities to exploit movement widely and freely, according to their ability level. (Nopiyanto, 2020). For this reason, the Group Learning Model, as a vehicle for the creation of innovative physical education learning, to make learning more interesting and fun, which is also beneficial for the development and growth of students.

\section{METHODS}

This research is an action research (Action Research). (Khasinah, 2013) Action research is a way for a group to organize a condition in which they can learn about their experiences and make their experiences accessible to others (Sthepen Kemmis, 2014). The form of action research was chosen on the basis of the premise that junior high school teachers are educational implementers who are able to identify learning problems but have limited ability to solve problems, especially those related to athletic learning in long jump material.

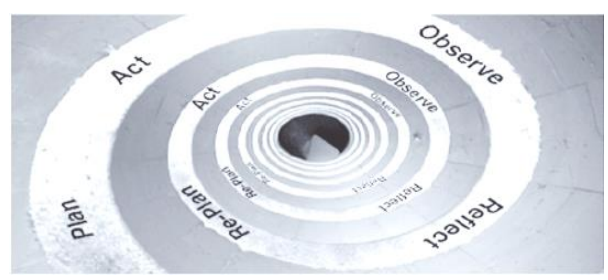

Figure 1. Model Model Spiral Kemmis and taggart

\section{Participants}

The subjects of this study were third grade students of SDN 1 Landasan Ulin Tengah Banjarbaru. With 27 students consisting of 16 male students and 11 female students.

\section{Sampling Procedures}

The sample selection used purposive sampling. According to Tongco, M. D. C. (2007) a sampling technique in which the researcher relies on his own judgment when selecting members of the population to participate in the study. The subjects of this study were third grade students of SDN 1 Landasan Ulin Tengah Banjarbaru. With 27 students consisting of 16 male students and 11 female students.

\section{Materials and Apparatus}

The collection of data used by researchers from the Learning Implementation Plan (RPP), Evaluation Instruments and Documentation. namely 1) Learning Implementation Plan (RPP). The lesson plan is made and used as a guide for researchers to organize the learning process. 2) Evaluation Instruments (Assessment). Assessment of 3 aspects, namely skills, knowledge and attitudes. For RPP and assessment sheet 3) The documentation in this study attempts to examine the description of how a study was carried out. (Barnawi, B., Junaedi, J., \& Rido, 2019). This activity is carried out for the time of taking the implementation of learning when the research is carried out. The 
resulting data is in the form of photos or images from these learning activities to strengthen the research data.

\section{Procedures}

General planning includes planning the time for the research to be carried out for approximately two months. The researcher held a meeting with the principal for consultation, and a meeting with the class teacher to discuss the steps for implementing the research. In addition, it is planned to arrange classroom conditions, prepare subject matter as well as the media and learning tools needed, make a grid for monitoring instruments for action monitoring and instrument grid for students' reasoning abilities about big ball games and the concept of learning models through a group approach to students.

\section{Design or Data Analysis}

In this research, the researcher will present the measurement results

The research data is in the form of quantitative data which will be calculated using the percentage descriptive technique. The percentage descriptive data analysis technique is intended to determine the status of the variable, namely to describe student learning outcomes through percentages According to (Nasution, 2017).

\section{RESULT}

This study aims to determine the effectiveness of the group learning model with the modification of the big ball game (hoop ball) in class III students of SDN 1
Landasan Ulin Tengah. The research data were obtained from the learning outcomes of students in the aspects of knowledge, skills and attitudes which were presented in two cycles as follows:

\section{Cycle I}

The first cycle was held on December 17, 2019, the following results were obtained:

Table 1. Recapitulation of 3 aspects assessment

\begin{tabular}{lcc}
\hline Average value & $\mathbf{7 0 , 1}$ & \\
\hline Complete students & 9 & $33,33 \%$ \\
\hline $\begin{array}{l}\text { Students who do not } \\
\text { complete }\end{array}$ & 18 & $66,67 \%$ \\
\hline
\end{tabular}

Based on the table above, the learning outcomes of the PJOK learning material manipulative movement of big ball games for grade III students of SDN 1 Landasan Ulin Tengah Banjarbaru, the average value of 70.1 , the number of students who reached KKM 75 was 9 students with a percentage of $33.33 \%$ and the number of participants. 18 students did not reach the KKM with a percentage of $66.67 \%$.

\section{Cycle II}

Based on the results of the evaluation of the manipulative motion learning of big ball games at the first meeting, the problems found were as follows: a) Students throw the ball at random b) Students find it difficult to accept the throw because the throw is missed. C) Students lack accuracy in throwing the hoop. 
Based on the results of evaluating problems in learning manipulative motion of big ball games, the researcher as an observer provides a solution to improve learning outcomes by implementing cooperative learning so that students get used to throwing, catching and shooting the ball.

The second cycle was held on December 23, 2019, the following results were obtained:

Table 2 Recapitulation of 3 aspects assessment

\begin{tabular}{lcc}
\hline Average value & $\mathbf{8 5 , 5}$ & \\
\hline Complete students & 27 & $100 \%$ \\
\hline $\begin{array}{l}\text { Students who do not } \\
\text { complete }\end{array}$ & 0 & $0 \%$ \\
\hline
\end{tabular}

Based on the table above, the learning outcomes of the PJOK learning material manipulative movement of big ball games for grade III students at SDN 1 Landasan Ulin Tengah Banjarbaru an average value of 85.5 the number of students who reached KKM 75 totaled 27 students with a percentage of $100 \%$ and the number of students who did not reach KKM numbered 0 students with a percentage of $0 \%$.

\section{DISCUSSION}

According to Arikunto (2017: 46) class action research cycle "In accordance with the provisions stated in the Decree of the Menpan and Bureaucratic Reform, action research (PTK, PTS, and PTSW) is carried out at least two cycles". So if in the second cycle the process and learning outcomes of students increase and reach the KKM, the research process can be ended.

At the first meeting, the researchers 'observations when students learned the manipulative motion of big ball games obtained an average value of 70.1 which is a category $(\mathrm{K})$ is lacking, while the minimum completeness criteria (KKM) 75 means that students' completeness in the learning process is still not This is complete because students do not understand and master the techniques in manipulative motion, big ball games can be seen during learning and playing, students still throw (bait) their friends carelessly so that the ball received is difficult to control. This can be seen from the low scores obtained by students.

Judging from the problems of students still lacking mastery of techniques and knowledge on manipulative movements of big ball games, researchers provide reinforcement in learning group play. After implementing the learning process for students by providing reinforcement by applying the cooperative learning model, it turned out that the results of student success data were 27 students of class III SDN 1 Landasan Ulin Tengah Banjarbaru received an average score of 85.5 from this average of 27 students have succeeded in achieving the minimum completeness criteria (KKM) with success indicators exceeding $80 \%$, so that learning manipulative movements of big ball games through learning group play is 
declared successful. These results are supported by several studies, namely (Wijayanto, 2012) about big ball games that have an impact on an activity. Furthermore, (Maulana, 2020) argued that cooperative learning has a good impact on the learning process. In addition, (Wahyudi, Budiman, \& Saepudin, 2018) in their research, cooperative methods improve big ball learning. From these theories, it shows that cooperative learning has a big impact on big ball learning.

\section{CONCLUSION}

Based on the data analysis, it was found that two meetings using the cooperative learning model of class III students of SDN 1 Landasan Ulin Tengah Banjarbaru showed that learning had increased. This is because the learning process of group play combined with game modification is preferred by students so that children tend not to be stiff and happy to move. In the study during the two meetings, the value obtained by students increased, meaning that the research hypothesis was obtained by applying cooperative learning to improve student learning outcomes in the manipulative motion material of big ball games class III SDN 1 Landasan Ulin Tengah Banjarbaru.

\section{ACKNOWLEDGEMENT}

Thanks to Dean of the FKIP ULM who have supported the writing of this article.

\section{REFERENCES}

Barnawi, B., Junaedi, J., \& Rido, R. (2019). Improve Teachers' Ability in Compiling Classroom Action Research Through Workshop Activities. Action Research Journal Indonesia (ARJI), 1(1), 1-12.

Johnson, D. W., \& Johnson, R. T. (2011). Cooperative learning. The encyclopedia of peace psychology.

Khasinah, S. (2013). Classroom action research. PIONIR: Jurnal Pendidikan, 4(1).

Kusmana, S. (2017). Pengembangan literasi dalam kurikulum pendidikan dasar dan menengah. Diglosia. Jurnal Pendidikan, Kebahasaan, Dan Kesusastraan Indonesia, 1(1).

Maulana, F. (2020). Implementasi Model Pembelajaran Kooperatif Untuk Meningkatkan Keterampilan Bermain Bola Besar Sepak Bola. Universitas Pendidikan Indonesia.

Nasution, L. M. (2017). Statistik deskriptif. Jurnal Hikmah, 14(1), 49-55.

Nopiyanto, Y. E. (2020). Hambatan Guru Pendidikan Jasmani Generasi 80-an dalam Pembelajaran Daring di Tengah Pandemi Covid-19. Jurnal Sporta Saintika, 5(2), 139-148.

Pramono, H. (2012). Pengaruh sistem pembinaan, sarana prasarana dan pendidikan latihan terhadap kompetensi kinerja guru pendidikan jasmani sekolah dasar di kota Semarang. Jurnal Penelitian Pendidikan, 29(1).

Rahayu, E. T. (2013). Strategi Pembelajaran Pendidikan Jasmani. CV. Alfabeta.

Stephen Kemmis, R. M. dan R. N. (2014). The Action Research Planner Doing Critical Participatory Action Research. Springer.

Subiantoro, F. (2013). Penerapan Model Pembelajaran Cooperative Learning (Jigsaw) Terhadap Hasil Belajar Service Bolavoli (Studi Pada Siswa Kelas VII SMPN 2 Tembelang Jombang). Jurnal Pendidikan Olahraga Dan Kesehatan, 1(1).

Suherman, A. (2016). Pengaruh penerapan model kooperatif tipe jigsaw dan tgt (teams game tournament) terhadap keterampilan sosial dan keterampilan 
bermain bolavoli. Jurnal Pendidikan Jasmani Dan Olahraga, 1(8), 8-15.

Vusparatih, D. S. (2014). Peranan komunikasi guru dalam implementasi kurikulum 2013. Humaniora, 5(1), 387-397.

Wahyudi, W., Budiman, D., \& Saepudin, E. (2018). Penerapan Model Pembelajaran Kooperatif Tipe TGT dalam Pembelajaran Permainan Bola Besar Berorientasi Sepak Takraw untuk Meningkatkan Kerjasama dan Keterampilan Bermain. TEGAR: Journal of Teaching Physical Education in Elementary School, 1(2), 1-9.

Wijayanto, E. Z. (2012). Pengaruh Pembelajaran Permainan Bola Besar Terhadap Tingkat Kesegaran Jasmani. ACTIVE: Journal of Physical Education, Sport, Health and Recreation, 1(1). 